\title{
Synthesis and crystal structures of thiocarbamoylsulfenamide zinc(II) complexes
}

\author{
Galina N. Khitrich, ${ }^{* a}$ Inna I. Seifullina ${ }^{a}$ and Anna V. Vologzhanina ${ }^{b}$
}

\author{
${ }^{a}$ I. I. Mechnikov Odessa National University, 65082 Odessa, Ukraine. Fax: +8 048723 3515; \\ e-mail: galina_khitrich@ukr.net \\ ${ }^{b}$ A. N. Nesmeyanov Institute of Organoelement Compounds, Russian Academy of Sciences, 119991 Moscow, \\ Russian Federation. Fax: +7 499135 5085; e-mail: vologzhanina@mail.ru
}

DOI: $10.1016 /$ j.mencom.2010.05.020

Studies of $N, N$-pentamethylene- and $N, N$-oxydiethylene- $N^{\prime}, N^{\prime}$-pentamethylenethiocarbamoylsulfenamide zinc(II) complexes by UV and NMR spectroscopy and X-ray diffraction showed the ligand coordination to the metal in a bidentate-chelate manner through the thionic sulfur atom and sulfenamide nitrogen atom with formation of five-membered metallacycle.

Sulfenamides are widely used in fine organic chemistry, rubber industry and agriculture. ${ }^{1}$ Thiocarbamoylsulfenamides, compared to widely used in rubber industry benzthiazol-2-ylsulfenamides, are more effective accelerators of rubber vulcanization and cause intensive structurization of gums. ${ }^{2}$ However, practical application of thiocarbamoylsulfenamides is limited up to now, probably due to their low stability and tendency to scorching.

We supposed that stability of thiocarbamoylsulfenamides can be enhanced upon complexation. In the present paper we report on synthesis ${ }^{\dagger}$ and physical-chemical investigation ${ }^{\ddagger}$ of interaction products between $\mathrm{ZnHal}_{2}(\mathrm{Hal}=\mathrm{Cl}, \mathrm{Br})$ and $N, N$-pentamethylene-

\footnotetext{
$\uparrow$ Compounds 1 and $\mathbf{2}$ were synthesised by oxidative condensation of the corresponding sodium dithiocarbamate (pentamethylene or oxydiethylene) and piperidine. ${ }^{3,5,6}$

General procedure for the synthesis of complexes 3-6. Complexes were obtained by interaction of the saturated solutions of $\mathbf{1}$ and $\mathbf{2}$ in diethyl ether and equimolar amounts of $\mathrm{ZnCl}_{2}$ or $\mathrm{ZnBr}_{2}$ in diethyl ether. Sediments were filtered, washed with diethyl ether and dried in air.

Dichloro(N,N-pentamethylene-N',N'-pentamethylenethiocarbamoylsulfenamide)zinc 3. Obtained from 1 ( $244 \mathrm{mg}, 1 \mathrm{mmol})$ and zinc dichloride (136 mg, $1 \mathrm{mmol})$. Yield, $333 \mathrm{mg}(87 \%)$. UV [ $\left.\lambda_{\max } / \mathrm{nm}\left(\varepsilon \times 10^{-3}\right)\right]: 235$, 287 (1:0.98). NMR, $\delta: 1.66\left(\mathrm{~m}, 6 \mathrm{H}, \mathrm{CH}_{2}\right), 1.79\left(\mathrm{~s}, 6 \mathrm{H}, \mathrm{CH}_{2}\right), 3.22$ (s, $\left.2 \mathrm{H}, \mathrm{CH}_{2}\right), 3.77\left(\mathrm{~s}, 2 \mathrm{H}, \mathrm{CH}_{2}\right), 4.25\left(\mathrm{~s}, 4 \mathrm{H}, \mathrm{CH}_{2}\right)$. Found (\%): N, 7.45; $\mathrm{S}$, 16.92; Cl, 18.76; Zn, 17.21. Calc. for $\mathrm{C}_{11} \mathrm{H}_{20} \mathrm{~N}_{2} \mathrm{~S}_{2} \mathrm{Cl}_{2} \mathrm{Zn}$ (\%): N, 7.36; S, 16.84; $\mathrm{Cl}, 18.62 ; \mathrm{Zn}, 17.18$.

Dibromo(N,N-pentamethylene- $\mathrm{N}$ ', N'-pentamethylenethiocarbamoylsulfenamide)zinc 4. Obtained from $1(244 \mathrm{mg}, 1 \mathrm{mmol})$ and zinc dibromide (225 mg, $1 \mathrm{mmol})$. Yield, $435 \mathrm{mg}(92 \%)$. UV $\left[\lambda_{\max } / \mathrm{nm}\left(\varepsilon \times 10^{-3}\right)\right]: 232$, 281 (1:0.89). NMR, $\delta: 1.61\left(\mathrm{~m}, 6 \mathrm{H}, \mathrm{CH}_{2}\right), 1.80\left(\mathrm{~s}, 6 \mathrm{H}, \mathrm{CH}_{2}\right), 3.33(\mathrm{~s}$, $2 \mathrm{H}, \mathrm{CH}_{2}$ ), 3.75 (s, 2H, $\mathrm{CH}_{2}$ ), 4.26 (s, 4H, $\mathrm{CH}_{2}$ ). Found (\%): N, 6.14; $\mathrm{S}$, 13.75; Br, 34.12; Zn, 13.98. Calc. for $\mathrm{C}_{11} \mathrm{H}_{20} \mathrm{~N}_{2} \mathrm{~S}_{2} \mathrm{Br}_{2} \mathrm{Zn}$ (\%): N, 5.96; S, 13.66; Br, 34.03; Zn, 13.93.

Dichloro(N,N-oxydiethylene- $\mathrm{N}^{\prime}, \mathrm{N}^{\prime}$-pentamethylenethiocarbamoylsulfenamide)zinc 5. Obtained from $2(246 \mathrm{mg}, 1 \mathrm{mmol})$ and zinc dichloride (136 mg, $1 \mathrm{mmol})$. Yield, $342 \mathrm{mg}(89 \%)$. UV [ $\left.\lambda_{\max } / \mathrm{nm}\left(\varepsilon \times 10^{-3}\right)\right]: 231,280$ (1:0.93). NMR, $\delta: 1.71$ (m, 6H, $\mathrm{CH}_{2}$-Pyp), 3.17, 3.89 (s, 4H, $\mathrm{CH}_{2}$-Morph), 3.79 (t, 4H, $\mathrm{CH}_{2} \mathrm{O}, J 4.5 \mathrm{~Hz}$ ), 3.82, 4.04 (s, 4H, $\left.\mathrm{CH}_{2}-\mathrm{Pyp}\right)$. Found (\%): N, 7.41; S, 16.87; Cl, 18.64; Zn, 17.14. Calc. for $\mathrm{C}_{10} \mathrm{H}_{18} \mathrm{~N}_{2} \mathrm{OS}_{2} \mathrm{Cl}_{2} \mathrm{Zn}$ (\%): N, 7.32; S, 16.76; Cl, 18.53; Zn, 17.09 .

Dibromo(N,N-oxydiethylene-N',N'-pentamethylenethiocarbamoylsulfenamide)zinc 6. Obtained from $2(246 \mathrm{mg}, 1 \mathrm{mmol})$ and zinc dibromide (225 mg, $1 \mathrm{mmol})$. Yield, $431 \mathrm{mg}(91 \%)$. UV [ $\left.\lambda_{\max } / \mathrm{nm}\left(\varepsilon \times 10^{-3}\right)\right]: 231,279$ (1:0.92). NMR, $\delta: 1.74$ (m, 6H, $\mathrm{CH}_{2}$-Pyp), 3.25, 3.84 (s, 4H, $\mathrm{CH}_{2}$-Morph), 3.82 (t, 4H, $\mathrm{CH}_{2} \mathrm{O}, J 4.5 \mathrm{~Hz}$ ), 3.83, 4.02 (s, $\left.4 \mathrm{H}, \mathrm{CH}_{2}-\mathrm{Pyp}\right)$. Found (\%): $\mathrm{N}, 6.11 ; \mathrm{S}, 13.71 ; \mathrm{Br}, 33.98 ; \mathrm{Zn}, 13.92$. Calc. for $\mathrm{C}_{10} \mathrm{H}_{18} \mathrm{~N}_{2} \mathrm{OS}_{2} \mathrm{Br}_{2} \mathrm{Zn}$ (\%): N, 5.94; S, 13.60; Br, 33.89; Zn, 13.86.
}

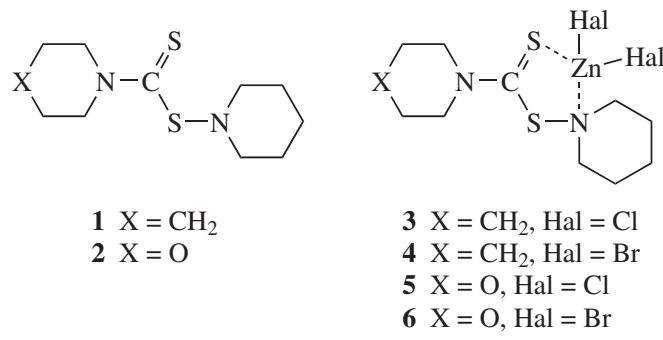

$N^{\prime}, N^{\prime}$-pentamethylenethiocarbamoylsulfenamide $\mathbf{1}$ and $N, N$-oxydiethylene- $N^{\prime}, N^{\prime}$-pentamethylenethiocarbamoylsulfenamide $\mathbf{2}$, complexes 3-6.

UV spectra of complexes 3-6 in contrast to those of ligands 1, 2 do not contain low intensity band corresponding to the transition of one electron of the lone pair located on the thionic sulfur in the excited state on $\pi$-antibonding orbital. This can be attributed to coordination of thionic sulfur by zinc. The downfield shift of signals of methylene group protons at the thiocarbamoyl nitrogen atom in ${ }^{1} \mathrm{H}$ NMR spectra of complexes 3-6 was observed, with their chemical shifts remaining unequivalent. At the same time, coordination of sulfenamide nitrogen by metal atom caused an upfield shift of the signals of methylene protons. Comparison of UV and NMR spectra of the complexes 3-6 showed their similarity.

The structures of compounds and coordination modes of the ligands were confirmed by X-ray investigation of $\mathbf{2}$ and $\mathbf{6}$ (Figure 1). ${ }^{\S}$ In accordance with obtained data, unit cell of 6 contains two independent molecules; bond lengths and angles of morpholine and piperidine fragments are typical of both the ligand and the complex. ${ }^{4}$ Heterocycles have chair conformation for all cases, although the piperidine cycle in $\mathbf{6}$ is inverted in comparison with non-coordinated $\mathbf{2}$. The ligand coordinates the zinc in a bidentate-chelate way with formation of five-membered metallacycle, two bromine atoms being the terminal ligands. Thus, the zinc coordination number is 4 and its coordination

\footnotetext{
Zinc in compounds was determined by complexonometry, ${ }^{7}$ chlorine, bromine and sulfur - by Schöniger, ${ }^{8}$ and nitrogen - by Dumas. ${ }^{8}$ Electronic spectra were recorded in acetonitrile using a Specord UV-VIS spectrophotometer. NMR spectra were recorded on a Bruker MSL-400 instrument with a working frequency of $400 \mathrm{MHz}$; measurements were performed on a $\delta$ scale using TMS as an internal reference and $\left(\mathrm{CD}_{3}\right)_{2} \mathrm{CO}$ as the solvent.
} 

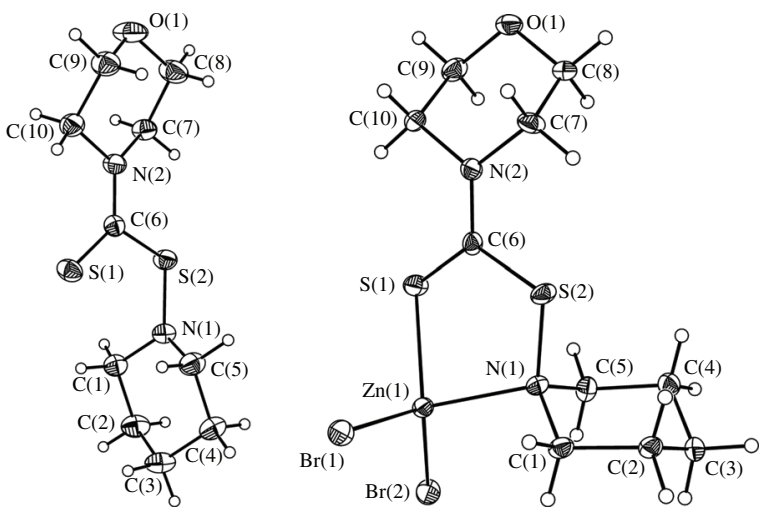

Figure 1 ORTEP view of 2 (left) and $\mathbf{6}$ (right), thermal ellipsoids are given with $p=50 \%$. Selected interatomic distances $(\AA)$ for 2: $\mathrm{C}(6)-\mathrm{N}(2)$ 1.334(2), C(6)-S(1) 1.666(2), C(6)-S(2) 1.799(2), S(2)-N(1) 1.654(2); and for 6: $\mathrm{Zn}-\mathrm{Br} 2.3401(6)-2.3601(6), \mathrm{Zn}-\mathrm{S}$ 2.337(1)-2.353(1), Zn-N 2.129(3)-2.135(3), C(6)-N(2) 1.320(4)-1.325(4), C(6)-S(1) 1.696(4)1.701(4), C(6)-S(2) 1.773(3)-1.776(3), S(2)-N(1) 1.740(3)-1.747(3).

$\S X$-ray crystallography. The crystals of $2\left(\mathrm{C}_{10} \mathrm{H}_{18} \mathrm{~N}_{2} \mathrm{OS}_{2}, M=246.38\right)$ are monoclinic, space group $P 2_{1} / c$, at $100 \mathrm{~K}: a=8.6270(6), b=6.5252(5)$ and $c=21.7831(15) \AA, \beta=94.629(1)^{\circ}, V=1222.2(2) \AA^{3}, Z=4, d_{\text {calc }}=$ $=1.339 \mathrm{~g} \mathrm{~cm}^{-3}, \mu=0.413 \mathrm{~cm}^{-1}, F(000)=528$.

The crystals of $6\left(\mathrm{C}_{10} \mathrm{H}_{18} \mathrm{Br}_{2} \mathrm{~N}_{2} \mathrm{OS}_{2} \mathrm{Zn}, M=471.57\right)$ are triclinic, space group $P \overline{1}$, at $100 \mathrm{~K}: a=10.434(1), b=12.020(1)$ and $c=14.256(3) \AA$, $\alpha=100.999(5)^{\circ}, \beta=102.663(5)^{\circ}, \gamma=110.171(4)^{\circ}, \quad V=1566.7(4) \AA^{3}$, $Z=4, d_{\text {calc }}=1.999 \mathrm{~g} \mathrm{~cm}^{-3}, \mu=6.925 \mathrm{~cm}^{-1}, F(000)=928$.

The intensities of reflections were collected with Bruker APEX2 CCD $[\lambda(\mathrm{MoK} \alpha)=0.71072 \AA, \omega$-scan $]$. The structures were solved by the direct method, all non-hydrogen atoms were found on difference Fourier maps and refined in anisotropic approximation. The positions of hydrogen atoms were calculated and included in refinement in isotropic approximation by the riding model with $U_{\text {iso }}=1.2 U_{\text {eq }}\left(C_{i}\right)$, where $U_{\text {eq }}(\mathrm{C})$ are equivalent thermal parameters of parent atoms.

The refinement converged for 2 to $w R_{2}=0.0983$ and GOF $=1.010$ (for 3249 independent reflections) and $R_{1}=0.0483$ [for 2683 observed reflections with $I>2 \sigma(I)$ ]; for 6 to $w R_{2}=0.0788$ and $\mathrm{GOF}=1.007$ (for 9018 independent reflections) and $R_{1}=0.0372$ [for 6593 observed reflections with $I>2 \sigma(I)]$. All calculations were performed using SHELXTL PLUS 5.0 program. ${ }^{10}$

CCDC 774842 and 774843 contain the supplementary crystallographic data for this paper. These data can be obtained free of charge from The Cambridge Crystallographic Data Centre via www.ccdc.cam.ac.uk/data_request/cif. For details, see 'Notice to Authors', Mendeleev Commun., Issue 1, 2010. polyhedron adopts distorted tetrahedron geometry. The N(1)$\mathrm{N}(2)-\mathrm{C}(6)-\mathrm{S}(1)-\mathrm{S}(2)$ atoms belong to a plane for both uncoordinated and coordinated ligand [the average displacement of atoms from the least-squared plane is equal to 0.03(1) and 0.07(2) $\AA$, respectively]. The coordination of the ligand by zinc causes elongation of the $\mathrm{C}=\mathrm{S}$ and $\mathrm{N}-\mathrm{S}$ bonds as well as shortening of the $\mathrm{C}-\mathrm{N}$ and $\mathrm{C}-\mathrm{S}$ bonds.

Taking into account good correlation between X-ray analysis, UV and NMR spectroscopy data in the case of compound $\mathbf{2}$ and complex 6, it is possible to conclude that all synthesized complexes are similar in the structure. The results obtained will be helpful for further study of vulcanization efficiency of the prepared compounds.

This work was supported in part by the President of the Russian Federation (project nos. MK-966.2008.3 and NSh-3019.2008.3).

\section{References}

1 I. V. Koval', Usp. Khim., 1996, 65, 452 (Russ. Chem. Rev., 1996, 65, 421).

2 G. A. Blokh, Organicheskie uskoriteli vulkanizatsii kauchukov (Organic Accelerators of Rubber Vulcanization), Khimiya, Leningrad, 1972, p. 560 (in Russian).

3 G. N. Khitrich, I. I. Seifullina and N. V. Khitrich, Visnyk ONU. Khimiya, 2007, 12, 78.

4 F. H. Allen, O. Kennard, D. G. Watson, L. Brammer, A. G. Orpen and R. Taylor, J. Chem. Soc., Perkin Trans. 2, 1987, S1.

5 G. E. P. Smith, G. Alliger, E. L. Carr and K. C. Young, J. Org. Chem., 1949, 14, 935.

6 I. I. Eytingon and N. P. Strel'nikova, Zh. Obshch. Khim., 1960, 30, 3137 (in Russian).

7 G. Shvartsenbakh and G. Flashka, Kompleksonometricheskoe titrovanie (Complexonometric Titration), Khimiya, Moscow, 1970, p. 360 (in Russian).

8 W. Schöniger, Mikrochim. Acta, 1955, 43, 123.

9 Ching Siang Yeh, Microchem. J., 1966, 11, 229.

10 G. M. Sheldrick, Acta Crystallogr., 2008, A64, 112.

Received: 16th December 2009; Com. 09/3436 